\title{
A Cross Country Study of Indirect Effect of IFRS Adoption on Earnings Management
}

\author{
Agustin Setya Ningrum*, Ratna Wardhani, and Aria Farah Mita
}

AFFILIATION:
Department of Accounting,
Universitas Indonesia, Depok,
Indonesia
*CORRESPONDENCE:
setyaningrum@ui.ac.id

THIS ARTICLE IS AVALILABLE IN:

http://journal.umy.ac.id/index.php/ai

DOI: $10.18196 /$ jai.2003124

\section{CITATION:}

Ningrum, A.S., Wardhani, R., \& Mita, A. F. (2019). A Cross Country Study of Indirect Effect of IFRS Adoption on Earnings Management. Journal of Accounting and Investment, 20(3), 198-212.

\section{ARTICLE HISTORY \\ Received:}

12 March 2019

\section{Reviewed:}

29 May 2019

Revised:

8 July 2019

\section{Accepted:}

11 September 2019

\begin{abstract}
The main purpose of this study is to investigate whether there is an indirect negative effect of IFRS adoption level on earnings management, through an increase of analyst coverage. This paper is motivated by the fact that IFRS adoption could increase the number of analysts who follow the companies. The existence of analysts will increase the role of oversight of the company, which will decrease earnings management practices. This study is a cross-country study using 3.786 firm years of entities among 30 countries. This study proves that there is indirect positive effect of IFRS adoption level on earnings management, through an increase of analyst coverage. Increase of analyst coverage will push companies to do earnings management practices. This study also confirms that IFRS adoption level has direct negative effect on earnings management. This paper develops new measurement of the IFRS adoption level based on information presented in the IFRS Jurisdiction Profile published by the IFRS Foundation. This measurement is different from previous studies, which generally use dummy variables. More than 100 countries have submitted the IFRS Profile to IFRS Foundation in 2012. Therefore, we can measure the level of IFRS adoption in many countries. This measurement becomes an additional contribution to further studies.
\end{abstract}

Keywords: IFRS adoption; Earnings management; Financial analyst; Analyst coverage; Analyst following; Discretionary accruals

\section{Introduction}

The integration of the global capital market underlies the need for accounting standards harmonization at the international level. Using a set of international accounting standards is expected to facilitate cross-border investment. The idea for a harmonization of accounting standards at the international level was followed by the establishment of the International Accounting Standards Committee (IASC) in 1973. In 2000, there was a reorganization that is the birth of the International Accounting Standards Board (IASB) replacing the IASC. The IASB was established with the aim to build a set of high-quality accounting standards (IASC, 1989 in Barth, Landsman, \& Lang, 2008). As a high-quality accounting standard and globally applied, IFRS has some specific characteristics such as the principle-based, elimination of some accounting method alternatives, requiring accounting measurement that reflects economic reality better (such as the use of fair value), and requiring more extensive disclosures. 


\section{Ningrum, Wardhani, \& Mita \\ A Cross Country Study of Indirect Effect of IFRS Adoption on Earnings Management}

The results of the previous studies showing the impact of the adoption of IFRS in the past decade already prove that the IFRS adoption may depress earnings management practices (Ajina, Bouchareb, \& Souid, 2013; Fuad \& Wijanarto, 2017; Houqe, van Zijl, Dunstan, \& Karim, 2012; Ismail, Kamarudin, Van Zijl, \& Dunstan, 2013; Montoya, 2018; Pelucio-Grecco, Geron, Grecco, \& Lima, 2014; Tze-yu, Ming-lei, \& Hsiao-chian, 2013; Zeghal, Chtourou, \& Fourati, 2012; Zeghal, Chtourou, \& Sellami, 2011). Past researches explain that the IFRS adoption may decrease earnings management practices through restrictions on accounting methods alternative selected by the management. The IFRS adoption could also suppress earnings management practices because IFRS requires more extensive disclosures.

The use of IFRS as international accounting standards will facilitate financial analysts in comparing performance and financial condition between firms, thereby increasing the quality of information produced by financial analysts (Tan, Wang, \& Welker, 2011). Financial analysts also benefit from wider-disclosure features in the notes to the financial statements (Kim \& Shi, 2012). Various disclosed information will assist financial analysts in understanding the performance and financial condition of the company in a more comprehensive and in-depth, and in turn could improve the accuracy of forecasts made by financial analysts (Hope, 2003). The magnitude of the benefits for financial analysts from IFRS adoption increases the tendency to follow companies that have adopted IFRS (Abdallah, Abdallah, \& Ismail, 2012; Cheng, 2012; Cuijpers \& Buijink, 2005; Kim \& Shi, 2012; Tan et al., 2011; Wang, Hou, \& Chen, 2012).

Financial analysts can be deemed to be external monitors of managers. They performed the oversight of what might happen in the firm (Healy \& Palepu, 2001; Jensen \& Meckling, 1976). Financial analysts are the external parties of companies, so they are more objective in overseeing the company. When the number of financial analysts who follow the company becomes more, the role of supervision by financial analysts will be stronger and can ultimately reduce the opportunistic behavior of management, including earnings management (Degeorge, Ding, Jeanjean, \& Stolowy, 2004, 2013; Martinez, 2010; Yu, 2008).

The explanation shows that there is a possibility that IFRS adoption level has indirect negative effect on earnings management, through the increasing number of financial analysts who follow the company. Based on this background, the main purpose in this study is to investigate whether the IFRS adoption level has an indirect negative effect on earnings management, through an increase of analyst coverage.

The entire previous research examined the effect of adopting IFRS on earnings management directly. There are no studies that examine the effect of adopting IFRS on earnings management indirectly. This research attempts to fill the research gap by examining the indirect effect of adopting IFRS on earnings management through analyst coverage. Most previous IFRS studies used dummy variables. This study uses different measurements of the level of IFRS adoption. We develop a score of IFRS adoption based on IFRS Jurisdiction Profile issued by the IFRS Foundation. This study is a cross-country 


\section{Ningrum, Wardhani, \& Mita \\ A Cross Country Study of Indirect Effect of IFRS Adoption on Earnings Management}

study with a sample of 30 countries. The study aims to capture variations in IFRS's adoption strategies in various countries.

Based on the explanation, the main contribution of this study is to provide evidence of the indirect effect of IFRS adoption on earnings management through analyst coverage. In addition, this study also develops a new measurement of IFRS adoption. This study also contributes to providing evidence of the benefits of adopting IFRS. This provides feedback on IASB policies and strategies in encouraging countries to adopt IFRS so far. For the analyst, this research provides an overview of the role of financial analysts in reducing earnings management practices. This can encourage financial analysts to increase the company's supervisory role.

\section{Literature Review and Hypotheses Development}

Agency relationship as a contract where a person or several people (acting as principal) employs another person (agent) to carry out work on behalf of the principal, including delegating the authority to make decisions to the agent (Jensen \& Meckling, 1976). Agency relationships lead to the emergence of information asymmetry problems. Information asymmetry is a condition where there is a difference in information between one party and another. Managers have greater access to company information compared to other parties who are not directly involved in running the company. Greater access to company information sometimes causes managers (agents) to take advantage of other parties (principal) (Scott, 2014). Information asymmetry can be overcome through the quality of financial reporting (Healy \& Palepu, 2001). Further they explained that there are three ways to improve the quality of financial reporting. First, by optimizing contracts between investors and company managers. The second way is by making policy about the disclosure of various information that must be made by the manager. And the last is by optimizing the functions of intermediaries, such as financial analysts and rating agencies. Intermediaries can improve the quality of information disclosure because intermediaries are external parties who are expected to be more objective in valuing companies.

Earnings management practices can be reduced through the application of high-quality accounting standards (Scott, 2014). The use of IFRS is expected to improve the quality of financial reporting and can minimize the problem of information asymmetry (Healy \& Palepu, 2001). Some researchers (Ball, Kothari, \& Robin, 2000; Daske, Hail, Leuz, \& Verdi, 2008; Amiram, 2012; Ahmed, Neel, \& Wang, 2013; Nijam \& Athambawa, 2016) state that the main objective of IFRS adoption is to improve transparency and quality of financial reporting (Hasan \& Rahman, 2017). The increased transparency and quality of financial reporting can reduce the possibility of earnings management practice (Dakata \& Hasnah, 2016).

One of the main characteristics of IFRS that can increase company transparency is extensive disclosure. Extensive disclosures would increase transparency to the users of financial statements so that users can evaluate the condition of the financial statements 


\section{Ningrum, Wardhani, \& Mita \\ A Cross Country Study of Indirect Effect of IFRS Adoption on Earnings Management}

and financial performance more closely. This can reduce the tendency of managers to take advantage of the information asymmetry that occurs between management and users of financial statements, including the conduct of earnings management (Scott, 2014).

Earnings management can be controlled by limiting accounting method alternatives that can be chosen by the management (Ashbaugh \& Pincus, 2001). Ewert and Wagenhofer (2005) also state that the accounting standards that restrict the choice of accounting methods will improve the quality of reported earnings. IFRS as international accounting standards has these characteristics (Ismail et al., 2013).

From the explanation, it can be concluded that the IFRS adoption lowers earnings management practices. This is consistent with the study results of Barth et al. (2008), Zeghal et al. (2011), Chua, Cheong, and Gould (2012), Houqe et al. (2012), Zeghal et al. (2012), Ismail et al. (2013), Tze-yu et al. (2013), Pelucio-Grecco et al. (2014), Fuad and Wijanarto (2017), Montoya (2018). Therefore, the first hypothesis in this study is:

$\boldsymbol{H}_{1}$ : The IFRS adoption level has a direct negative effect on earnings management.

Harmonization of accounting standards benefits companies and financial statement users, as well as financial analysts. IFRS adoption can reduce the cost of acquiring and processing accounting information by financial analysts. This is because financial analysts do not need to learn a variety of local accounting standards. A good understanding of international accounting standards, in this case the IFRS, will help financial analysts in understanding the financial statements of companies from different countries and compare the financial condition and performance among companies in various countries (Tan et al., 2011). This statement is in accordance with the research results of Ortega (2012), who found that IFRS adoption improves the comparability of financial statements.

The extensive disclosure level would assist users, including financial analysts, in analyzing the performance and financial condition of the company in a deeper way; making it easier for financial analysts in producing earnings forecasts and improving the accuracy of forecast (Hope, 2003). Measurement at fair value enables users of financial statements to find out more relevant information about the gain or loss (Tan et al., 2011). This, of course, helps financial analysts in making a more accurate forecast.

The description explains the benefits of IFRS adoption for financial analysts. The benefits to be gained increase the tendency of financial analysts to follow the companies who apply IFRS. The results of previous studies (Abdallah et al., 2012; Cheng, 2012; Cuijpers \& Buijink, 2005; Kim \& Shi, 2012; Tan et al., 2011; Wang et al., 2012) show that IFRS adoption has a positive effect on the number of financial analysts who follow the company. Thus, the second hypothesis in this study is:

$\boldsymbol{H}_{2}$ : The IFRS adoption level has a positive effect on analyst coverage. 


\section{Ningrum, Wardhani, \& Mita \\ A Cross Country Study of Indirect Effect of IFRS Adoption on Earnings Management}

The existence of financial analysts can reduce information asymmetry between management and investors through effective monitoring activities (Healy \& Palepu, 2001; Jensen \& Meckling, 1976). Dyck, et al. (2006) found the evidence that financial analysts are external parties who have greater role in detecting fraud rather than the Securities and Exchange Commission (SEC) and the external auditors (Yu, 2008).

Financial analysts can be actively involved in the supervision of the company. This is because financial analysts intensively monitor the development of the company. In addition, analysts also have sufficient capacity, so they can quickly detect errors or mistakes made by the company. Financial analysts are external parties of the company, so they are more objective in overseeing the company. In addition, financial analysts also have access informing the market what is happening in the company, thus increasing the power of financial analysts in conducting oversight role. The effectiveness of financial analysts in running the oversight function is also driven by the desire to maintain their reputation (Degeorge et al., 2013). The reputation of financial analysts is evaluated by how accurate the forecasts or recommendations made by financial analysts. Several previous studies, such as Yu (2008), Martinez (2010), Degeorge et al. (2004, 2013), Xu, Li, and Liu (2013), Hong, Huseynov, and Zhang (2014), Abaoub and Nouri (2015), found the evidence that analyst coverage negatively affect earnings management. These results indicate that there is a role of monitoring company run by financial analysts. Therefore, the third hypothesis in this study is:

$\boldsymbol{H}_{3}$ : Analyst coverage has a negative effect on earnings management.

Based on the description in developing hypotheses 3 and 4, it can be concluded that the IFRS adoption level will have an impact on increasing number of financial analysts who follow the company (Abdallah et al., 2012; Cheng, 2012; Cuijpers \& Buijink, 2005; Kim \& Shi, 2012; Tan et al., 2011; Wang et al., 2012). Increasing number of financial analysts will strengthen the oversight role carried by financial analysts, and in turn suppress the practice of earnings management (Abaoub \& Nouri, 2015; Degeorge et al., 2004, 2013; Hong et al., 2014; Martinez, 2010; Xu et al., 2013; Yu, 2008). So, it can be hypothesized that:

$\boldsymbol{H}_{4}$ : The IFRS adoption level has an indirect negative effect on earnings management, through analyst coverage.

$\mathrm{H}_{3}$

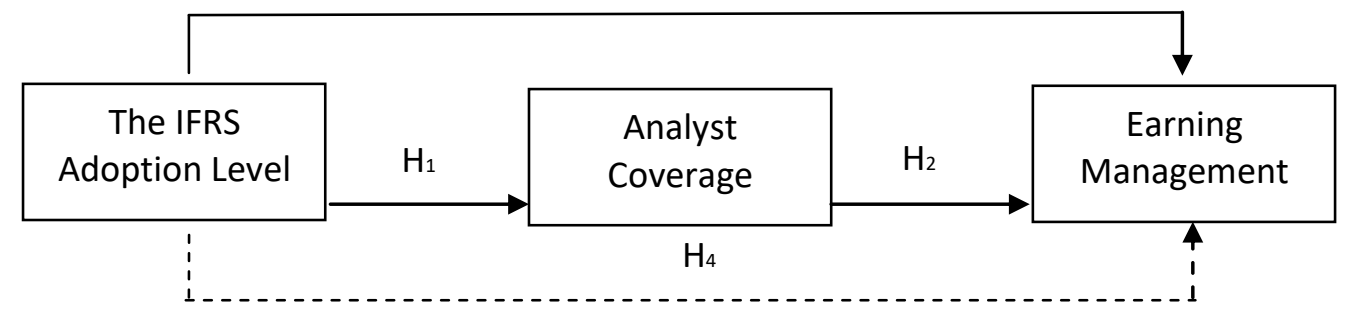

Figure 1 Research Framework 
Based on hypotheses developed, research frame work is formulated as shown in Figure 1.

\section{Research Method}

\section{Sample Selection}

This study is a cross-country research that tests the effect of IFRS adoption on earnings management practices in 2012. The selected year is intended to observe the current status of IFRS adoption by countries around the world. Samples were taken from 30 countries, which are selected based on the following criteria: (1) a member of the International Federation of Accountants (IFAC) and have the IFRS Jurisdiction Profile data and (2) have associated data of country-level variables, such as GDP data and market capitalization. From the initial selection, it was obtained 82 countries that met these criteria. Then 30 countries with the largest market capitalization have been chosen. The use of market capitalization as selection criteria of countries is related to the financial analysts' data. Thirty countries represent approximately $53 \%$ of world market capitalization, therefore it is expected that the results of this study could be widely generalized.

The sampling method used is purposive sampling, a method of sample selection based on certain criteria. The sample selection criteria are: (a) followed by financial analysts; (b) not included in the financial or unclassified industry based on SIC code classification. The financial industry is excluded from the sample because it has more stringent regulations than other industries; (c) not being in the industry with a number of companies of less than 10. It is associated with the regression model of Kothari, Leone, and Wasley (2005) in the calculation of earnings management variables; (d) having complete data for all study variables for the period 2011-2012. The 2011 data is required for calculating earnings management variables and a dummy variable of previous period loss; and (e) having data of external auditors.

Model 1 is to see the effect of the IFRS adoption level on analyst coverage $\left(\mathrm{H}_{2}\right)$. The main variables in Model 1 are the IFRS adoption level (independent variable) and analyst coverage (dependent variable). The company-level control variables used in model 1 are the size of the company, profitability, company growth rate, and audit quality. While the country-level control variables are the level of economy and the legal origin.

$$
\begin{gathered}
A C_{i j}=\alpha_{0}+\alpha_{1} I F R S_{j i}+\alpha_{2} S I Z E_{i f}+\alpha_{3} R O A_{i j}+\alpha_{4} G R O W_{i j}+\alpha_{5} A U D_{i f}+\alpha_{6} G D P_{j i}+\alpha_{7} L E G_{j i} \\
+\varepsilon_{i j}(1)
\end{gathered}
$$

Model 2 is used to test hypothesis 1 the direct effect of IFRS adoption level on earning management $(\mathrm{H} 1)$ and the effect of analyst coverage on earnings management $(\mathrm{H} 3)$. The main independent variables in model 2 are the IFRS adoption level and analyst coverage, while the dependent variable is earnings management. Model 2 also incorporates some 
control variables such as the size of the company, debt, and the company growth rate, and dummy variable of previous period loss. Country-level control variables used are the level of economy and legal origin.

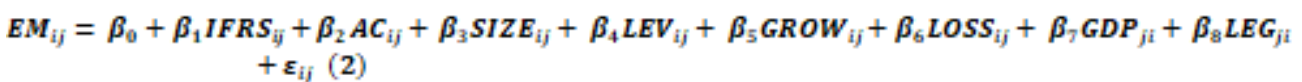

To determine the indirect effect of the IFRS adoption level on earning management $(\mathrm{H} 4)$, a joint test of Model 1 and Model 2 will be conducted using the Structural Equation Modeling (SEM) feature in STATA.

\section{Variables Operationalization}

The IFRS adoption level will be measured by developing a score of IFRS adoption based on IFRS Jurisdiction Profile issued by the IFRS Foundation. IFRS Foundation has completed 130 profiles, including jurisdiction included in the G20. IFRS Jurisdiction Profile was developed based on various sources of information, including a survey of accounting standards constituent and other relevant organizations throughout the world. The survey was conducted from August to December 2012. The published IFRS Jurisdiction Profile has accommodated review results. The following are the steps in calculating IFRS adoption score:

1. Creating instruction of assigning score for each question by (a) identifying all variations of answers for each question, and (b) providing score for each answer variation. The score ranges from 0 to a certain value, depending on the amount of answer variation in each question.

2. Providing score for the answer in each question according to scoring instructions.

3. Weighting value to each question with a maximum value in the question (0 to 1 ).

4. Summing the weighted values for all the questions in each jurisdiction (max. score is 18).

5. Calculating scores of IFRS adoption by dividing the total score by the total maximum score.

The measurement of analyst coverage variables is based on the research of Degeorge et al. (2013), which is the natural logarithm of $(1+$ the number of financial analysts who follow the company). The level of earnings management is measured by the absolute value of discretionary accruals developed by Kothari et al. (2005). The reason for choosing the model of Kothari et al. (2005) is that the model is the latest model of discretionary accruals and has been widely used in many studies, including the study of the effect of IFRS adoption on earnings management (Ajina et al., 2013; Dimitropoulos, Asteriou, Kousenidis, \& Leventis, 2013; Zeghal et al., 2011) 


\section{Ningrum, Wardhani, \& Mita \\ A Cross Country Study of Indirect Effect of IFRS Adoption on Earnings Management}

\section{Result and Discussion}

Using the sample selection criteria, the number of observations used in this study is 3.786 companies. The market capitalization for 3.786 companies is $68 \%$ of the total market capitalization in 30 countries. So, it can be concluded that the sample is fairly representative of the population in those countries.

Table 1 shows the descriptive statistics for all variables in this study. The level of earnings management (EM) for the whole sample is between $0.00002-0.80659$. The lowest level of earnings management is found in Korean companies. For analyst coverage, fifty percent of the research sample has a relatively small number of analysts following (1-4). However, there are companies with a high number of analysts following, such as KIA Motors, Samsung Electronics, and SK Hynix, which has 40 analysts following.

The average value of the IFRS adoption level for the 30 countries is 0.740 . The country with the highest level of IFRS adoption is Australia $(0,940)$. Meanwhile, Indonesia and Thailand are the countries with the lowest level of adoption of IFRS (0.120). Based on the analysis of the IFRS Jurisdiction Profile answers, it can be concluded that there is a strong commitment from the various countries in supporting the harmonization of international accounting standards, that IFRS has been used extensively, both for local companies and foreign companies, and that there are 18 countries that have modified the IFRS at the various level.

Table 1 Descriptive Statistics

\begin{tabular}{lcrrrrr}
\hline & Observation & \multicolumn{1}{c}{ Mean } & \multicolumn{1}{c}{ Std. Dev } & \multicolumn{1}{c}{ Median } & \multicolumn{1}{c}{ Min } & \multicolumn{1}{c}{ Max } \\
\hline EM & 3,786 & 0.10056 & 0.16262 & 0.04294 & 0.00002 & 0.80659 \\
AC & 3,786 & 6.45985 & 6.14631 & 4.00000 & 1.00000 & 40.00000 \\
\hline IFRS & 3,786 & 0.70499 & 0.20084 & 0.80556 & 0.12037 &., 93981 \\
\hline \multicolumn{2}{l}{ Control Variables } & & & & & \\
SIZE & 3,786 & $5,602,577$ & $19,200,000$ & $1,054,315$ & 363 & $412,000,000$ \\
LEV & 3,786 & 0.21176 & 0.17609 & 0.19240 & 0.00000 & 1.07261 \\
ROA & 3,786 & 6.46207 & 8.62032 & 5.80000 & -27.72000 & 40.13000 \\
GROW & 3,786 & 0.12469 & 0.44883 & 0.05793 & -0.99419 & 5.41880 \\
GDP & 3,786 & 37,579 & 20,188 & 39,746 & 1,257 & 99,636 \\
AUD & 3,786 & & & & & $82.44 \%$ \\
\hline LOSS & 3,786 & & & & & $11.65 \%$ \\
LEG & 3,786 & & & & & $48.94 \%$ \\
\hline
\end{tabular}

EM: the level of earnings management company measured by the absolute value of discretionary accruals; AC: analyst coverage measured by $\ln (1+\#$ analyst); IFRS: level of IFRS adoption of the country as measured by a score of IFRS adoption based on IFRS Jurisdiction Profile; SIZE: the size of the company measured by In(total assets in US Dollar); LEV: the company's debt level as measured by the ratio of debt to assets; ROA: the company's profitability as measured by return on assets and is expressed in \%; GROW: growth rate of the company as measured by revenue growth; AUD: audit quality of the company (1 for Big-4); LOSS: loss in the previous period (1 for companies that has loss in the previous period); GDP: the level of the country's economy as measured by log (GDP per capita in US dollars); LEG: legal origin of country (1 to common law). For descriptive statistics, numbers presented is not made in In or log. 
The results of SEM testing for model 1 and 2 are presented in Table 2. Results of the Model 2 testing show that the IFRS adoption level has significant negative coefficient. It can be concluded that the IFRS adoption level has a negative effect on earnings management. Thus Hypothesis 1 is supported. The results of these tests show a consistency with previous researches that found a negative effect of the IFRS adoption on earnings management (Barth et al., 2008; Chua et al., 2012; Fuad \& Wijanarto, 2017; Houqe et al., 2012; Ismail et al., 2013; Montoya, 2018; Pelucio-Grecco et al., 2014; Tzeyu et al., 2013; Zeghal et al., 2012; Zeghal et al., 2011). The negative influence of IFRS adoption level on earnings management is due to the restriction of accounting method alternatives that can be chosen by management. In addition, the level of disclosure required by IFRS also enables users of financial statements to carefully evaluate the performance and financial condition carefully. Thus, the probability of detecting earnings management activities becomes increasing. This will reduce the tendency of management to perform earnings management practices.

Table 2 Results of SEM Testing for Model 1 and 2

\begin{tabular}{|c|c|c|c|c|}
\hline & $\begin{array}{c}\text { Direction } \\
\text { Expectations }\end{array}$ & Coefficient & z-stats & $P>|z|$ \\
\hline \multicolumn{5}{|l|}{ Model 1: } \\
\hline \multicolumn{5}{|l|}{ Dependent Variable $=\mathrm{AC}$} \\
\hline IFRS & $\mathrm{H}_{2}:(+)$ & 0.40246 & 6.99 & $0.000 *$ \\
\hline SIZE & $(+)$ & 0.27394 & 47.09 & $0.000 *$ \\
\hline ROA & $(+)$ & 0.01134 & 9.55 & $0.000 *$ \\
\hline GROW & $(+)$ & 0.03695 & 1.71 & $0.0435 * * *$ \\
\hline AUD & $(+)$ & 0.13873 & 5.22 & $0.000 *$ \\
\hline GDP & $(+/-)$ & -0.12485 & -4.75 & $0.000 * *$ \\
\hline LEG & $(+)$ & -0.02345 & -1.10 & 0.136 \\
\hline \multicolumn{5}{|l|}{ Model 2: } \\
\hline \multicolumn{5}{|l|}{$\overline{\text { Dependent Variable }=\mathrm{EM}}$} \\
\hline IFRS & $H_{1}:(-)$ & -0.06442 & -4.39 & $0.000 *$ \\
\hline$A C$ & $\mathbf{H}_{3}:(-)$ & 0.02527 & 6.23 & $0.000 *$ \\
\hline SIZE & $(+/-)$ & -0.01277 & -6.33 & $0.000 * *$ \\
\hline LEV & $(+/-)$ & -0.05550 & -3.74 & $0.000 * *$ \\
\hline GROW & $(+)$ & 0.06246 & 11.45 & $0.000 *$ \\
\hline LOSS & $(+)$ & 0.02526 & 3.26 & $0.000 *$ \\
\hline GDP & $(+/-)$ & 0.08610 & 13.18 & $0.000 * *$ \\
\hline LEG & $(-)$ & 0.09807 & 18.32 & $0.000 *$ \\
\hline Direct effect: IFRS ke EM & $(-)$ & -0.06442 & -4.39 & $0.000 *$ \\
\hline Indirect effect: IFRS ke EM & $\mathbf{H}_{4}:(-)$ & 0.01017 & 4.65 & $0.000 *$ \\
\hline Total effect: IFRS ke EM & & -0.05425 & -3.71 & $0.000 *$ \\
\hline $\mathrm{N}$ & & & & 3.786 \\
\hline$R$-squared Model 1 & & & & 0.40883 \\
\hline$R$-squared Model 2 & & & & 0.17332 \\
\hline CFI & & & & 0.978 \\
\hline TLI & & & & 0.897 \\
\hline SRMR & & & & 0.011 \\
\hline
\end{tabular}

Results of the Model 1 testing show that the IFRS adoption level has a significant positive coefficient. So, it can be concluded that the IFRS adoption level has a positive 


\section{Ningrum, Wardhani, \& Mita \\ A Cross Country Study of Indirect Effect of IFRS Adoption on Earnings Management}

effect on analyst coverage. Therefore, Hypothesis 2 is supported. The results of this study are consistent with previous ones (Abdallah et al., 2012; Cheng, 2012; Cuijpers \& Buijink, 2005; Kim \& Shi, 2012; Tan et al., 2011; Wang et al., 2012). Financial analysts tend to follow companies that have adopted IFRS because IFRS adoption provides many benefits for financial analysts, such as the decline in analyst forecast error after IFRS has been adopted (Cheong, Kim, \& Zurbruegg, 2010; Jiao, Koning, Mertens, \& Roosenboom, 2012 ), the decrease in the cost of financial analysts in acquiring and processing accounting information because they do not need to learn a variety of accounting standards, and facilitating financial analysts to compare the financial statements between companies from different countries (Tan et al., 2011).

This study predicts that the high number of analysts following will strengthen the role of oversight so that it can reduce earnings management. From the results of Model 2 testing, it is known that analyst coverage has a significant positive coefficient. This means that analyst coverage is, in fact, have a positive effect on earnings management. Thus, Hypothesis 3 is not supported.

To determine the indirect effect of the IFRS adoption level on earning management $\left(\mathrm{H}_{4}\right)$, a joint test of Model 1 and Model 2 will be conducted using the Structural Equation Modeling (SEM). The results show that the indirect effect of the IFRS adoption level on earning management has a significant positive coefficient. A positive coefficient indicates that the indirect effect is having a positive direction. Thus, Hypothesis 4 cannot be supported. It is also proven by the test results of Hypothesis 2 and 3 , that shows that the IFRS adoption level has a positive effect on analyst coverage and analyst coverage has also a positive effect on earnings management.

The existence of financial analysts provides pressure for companies to achieve targeted profit from financial analysts. This pressure arises because investors use forecasts by financial analysts as a basis for making investment decisions. The existence of such pressure encourages companies to undertake earnings management, both to reach the targeted profit of the current financial analysts or to manage the expectations of financial analysts, therefore, facilitating the achievement of profit targets in the future. Research results of Degeorge, Patel, and Zeckhauser (1999) support this statement. The study tried to identify the factors driving companies to do earnings management. The results showed that the company did earnings management to achieve the three thresholds: reaching positive earnings, maintaining the company's performance, and achieving predicted earnings from financial analysts.

Companies are increasingly focusing on the earnings forecast made by financial analysts, and even make the targeted profit as one of the benchmarks that must be reached or exceeded. This is because of the importance of the analyst forecast to investors. Investors rely heavily on information provided by financial analysts because the information is more relevant (Ramnath et al., 2008 in Habib \& Hossain, 2008). When investors use analysts forecast in making investment decisions, investors have expectations that the company's performance will equal or exceed the forecasts made by financial analysts. 


\section{Ningrum, Wardhani, \& Mita \\ A Cross Country Study of Indirect Effect of IFRS Adoption on Earnings Management}

Management put some effort to reach or exceed financial analysts' earnings targets due to the urge to obtain high return of shares. This is evidenced by the results of research Kasznik and McNichols (2002) and (Bartov, Givoly, \& Hayn, 2002). Management became more compelled to achieve profit targets from financial analysts when the profit target is associated with bonus scheme of achievement. Matsunaga and Park (2001) provide evidence that there was a decline in CEO bonus when the quarterly profit was smaller than the profit financial analysts expected or than the quarterly profit in the previous period.

Conducting earnings management is not only to achieve financial analysts' earnings targets but also to manage the expectations of financial analysts in the future. This mechanism is intended to make the next targeted profits by financial analysts easily achieved by the company. Research of (Bartov et al., 2002) proved that the company's success in achieving the targeted profit is because of the ability of company in managing the expectations of financial analysts.

\section{Conclusion}

This study is a cross-country study with a sample of 3,786 companies from 30 countries. Countries used as samples are originating from different regional and having a different status of the IFRS adoption. It is intended to capture the impact of the IFRS adoption on various levels. From the content analysis of IFRS Jurisdiction Profile, there is a commitment from many countries in supporting the use of IFRS as international accounting standards. Most countries prove their commitment by requiring or permitting the use of IFRS by local and foreign companies listed on the stock exchange in the country. From the calculation of IFRS adoption score in the 30 states, the average score is 0.740 . This indicates that the level of adoption of IFRS in 30 countries is quite high.

This study provides evidence of a direct negative effect of the IFRS adoption on earnings management. The results of this study also indicate that the IFRS adoption level increases the level of analyst coverage. These results are consistent with those of previous studies. This study also shows that analyst coverage has a negative effect on earning management practice. The existence of financial analysts actually raises the pressure for companies to achieve the targeted profit made by financial analysts (Degeorge et al., 1999). These pressures encourage companies to undertake earnings management practices. From these results, it can be concluded that the level of IFRS adoption has an indirect positive effect on the level of earnings management, through analyst coverage.

This study has several limitations. First, the observation period for this study is only 1 year. For further research, it is recommended to use a longer period of observation. The next limitation is related to earnings management measurement. This study only uses one measure of earnings management, discretionary accruals. Further studies are encouraged to perform development by using various measures of earnings 
management and run robustness tests using several models of discretionary accruals. IFRS adoption is expected to attract more financial analysts or foreign investors. In this study, there was no separation between local and foreign financial analysts. So, it cannot be concluded whether the adoption of IFRS has an effect on increasing the number of local, foreign, or both financial analysts. It is recommended to separate local analysts from foreign analysts as conducted by Tan et al. (2011).

\section{Appendix}

Table 3 The initiation year of IFRS adoption in 30 sample countries

\begin{tabular}{lclc}
\hline \multicolumn{1}{c}{ Countries } & $\begin{array}{c}\text { The initiation year } \\
\text { of IFRS adoption }\end{array}$ & \multicolumn{1}{c}{ Countries } & $\begin{array}{c}\text { The initiation year } \\
\text { of IFRS adoption }\end{array}$ \\
\hline Australia & 2007 & Malaysia & 2012 \\
Austria & 2005 & Mexico & 2008 \\
Belgium & 2005 & Netherlands & 2005 \\
Brazil & 2007 & New Zealand & 2005 \\
Canada & 2011 & Norway & 2005 \\
Chile & 2009 & Pakistan & 2005 \\
Denmark & 2005 & Russia & 2012 \\
France & 2005 & Saudi Arabia & 2012 \\
Germany & 2005 & Singapore & 2007 \\
Hong Kong & 2005 & South Africa & 2011 \\
India & 2016 & Spain & 2005 \\
Indonesia & 2012 & Switzerland & 2005 \\
Italy & 2005 & Thailand & 2013 \\
Japan & 2008 & Turkey & 2005 \\
Korea & 2011 & United Kingdom & 2005 \\
\hline
\end{tabular}

Source: https://www.iasplus.com/en/jurisdictions, retrieved June $17^{\text {th }}, 2019$

\section{References}

Abaoub, E., \& Nouri, Y. (2015). Earnings Management and Analyst Coverage Changes Around Ifrs Implementation: Evidence From France. International Journal of Business and Finance Research, 9(3), 83-94. Retrieved from www.theIBFR.com

Abdallah, A. A. N., Abdallah, W., \& Ismail, A. (2012). Do accounting standards matter to financial analysts? An empirical analysis of the effect of cross-listing from different accounting standards regimes on analyst following and forecast error. International Journal of Accounting, 47(2), 168-197. https://doi.org/10.1016/j.intacc.2012.03.002

Ajina, A., Bouchareb, M., \& Souid, S. (2013). Corporate governance mechanisms and earnings management after and before the adoption of IFRS. The Business \& Management Review, 3(4), 147-163.

Ashbaugh, H., \& Pincus, M. (2001). Domestic Accounting Standards , International Accounting Standards, and the Predictability of Earnings. Journal of Accounting Research, 39(3), 417-434. https://doi.org/10.1111/1475-679x.00020

Ball, R., Kothari, S. P., \& Robin, A. (2000). The Effect of International Institutional Factors 


\section{Ningrum, Wardhani, \& Mita \\ A Cross Country Study of Indirect Effect of IFRS Adoption on Earnings Management}

on Properties of Accounting Earnings. Journal of Accounting and Economics 29 (1), 1-51. https://doi.org/10.1016/S0165-4101(00)00012-4

Barth, M. E., Landsman, W. R., \& Lang, M. H. (2008). International accounting standards and accounting quality. Journal of Accounting Research, 46(3), 467-498. https://doi.org/10.1111/i.1475-679X.2008.00287.x

Bartov, E., Givoly, D., \& Hayn, C. (2002). The rewards to meeting or beating earnings expectations. Journal of Accounting and Economics, 33(2), 173-204. https://doi.org/10.1016/s0165-4101(02)00045-9

Cheng, C. S. A. (2012). Discussion of Voluntary IFRS Adoption, Analyst Coverage, and Information Quality: International Evidence. Journal of International Accounting Research, 11(1), 77-82. https://doi.org/10.2308/jiar-10223

Cheong, C. S., Kim, S., \& Zurbruegg, R. (2010). The impact of IFRS on financial analysts' forecast accuracy in the Asia-Pacific region: The case of Australia, Hong Kong and New Zealand. Pacific Accounting Review, 22(2), 124-146. https://doi.org/10.1108/01140581011074511

Chua, Y. L., Cheong, C. S., \& Gould, G. (2012). The Impact of Mandatory IFRS Adoption on Accounting Quality: Evidence from Australia. Journal of International Accounting Research, 11(1), 119-146. https://doi.org/10.2308/jiar-10224

Cuijpers, R., \& Buijink, W. (2005). Voluntary adoption of non-local GAAP in the European Union: A study of determinants and consequences. European Accounting Review, 14(3), 487-524. https://doi.org/10.1080/0963818042000337132

Dakata, M. N., \& Hasnah, K. (2016). IFRS Adoption and Earnings Management: Moderating Role of Institutional Ownership in Nigeria. International Journal of Management Research \& Review, 6(12), 1685-1691.

Degeorge, F., Ding, Y., Jeanjean, T., \& Stolowy, H. (2004). Do Financial Analysts Curb Earnings Management? International Evidence.

Degeorge, F., Ding, Y., Jeanjean, T., \& Stolowy, H. (2013). Analyst coverage, Earnings management and financial development: An international study. Journal of Accounting and Public Policy, 32(1), 1-25. https://doi.org/10.1016/j.jaccpubpol.2012.10.003

Degeorge, F., Patel, J., \& Zeckhauser, R. (1999). Earnings Management to Exceed Thresholds. The Journal of Business, 72(1), 1-33. https://doi.org/10.1515/9781400829125-021

Dimitropoulos, P. E., Asteriou, D., Kousenidis, D., \& Leventis, S. (2013). The impact of IFRS on accounting quality: Evidence from Greece. Advances in Accounting, 29(1), 108 123. https://doi.org/10.1016/j.adiac.2013.03.004

Fuad, \& Wijanarto, W. T. (2017). How mandatory IFRS adoption changes firms' opportunistic behavior: Empirical evidences from the earnings management perspective. Academy of Accounting and Financial Studies Journal, 21(2), 1-10.

Habib, A., \& Hossain, M. (2008). Do managers manage earnings to "just meet or beat" analyst forecasts? Evidence from Australia. Journal of International Accounting, Auditing and Taxation, 17(2), 79-91. https://doi.org/10.1016/j.intaccaudtax.2008.07.004

Hasan, M. T., \& Rahman, A. A. (2017). Elk Asia Pacific Journal of Finance and Risk Management Ifrs Adoption and Earnings Management: a Review and Justification of Earnings Management Model for Developing Countries. ELK Asia Pasific Journal of Finance and Risk Management, 8(3). https://doi.org/10.16962/EAPJFRM/issn

Healy, P. M., \& Palepu, K. G. (2001). Information asymmetry, corporate disclosure, and the capital markets: A review of the empirical disclosure literature. Journal of Accounting and Economics, 31(1-3), 405-440. https://doi.org/10.1016/S0165-4101(01)00018-0

Hong, Y., Huseynov, F., \& Zhang, W. (2014). Earnings Management and Analyst Following: A Simultaneous Equations Analysis. Financial Management, 43(2), 355-390. 


\section{https://doi.org/10.1111/fima.12043}

Hope, O. (2003). Disclosure Practices, Enforcement of Accounting Standards, and Analysts' Forecast Accuracy: An International Study. Journal of Accounting Research, 41(2): 235272. https://doi.org/10.1111/1475-679x.00102

Houqe, M. N., van Zijl, T., Dunstan, K., \& Karim, A. K. M. W. (2012). The Effect of IFRS Adoption and Investor Protection on Earnings Quality Around the World. International Journal of Accounting, 47(3), 333-355. https://doi.org/10.1016/j.intacc.2012.07.003

IFRS Application Around the World, Jurisdictional Profile. Retrieved January, 9, 2014, from https://www.ifrs.org/-/media/feature/around-the-world/jurisdiction-profiles. https://www.iasplus.com/en/jurisdictions, retrieved June, 17, 2019.

Ismail, W. A. W., Kamarudin, K. A., Van Zijl, T., \& Dunstan, K. (2013). Earnings quality and the adoption of IFRS-based accounting standards: Evidence from an emerging market. Asian Review of Accounting, 21(1), 53-73. https://doi.org/10.1108/13217341311316940

Jensen, M., \& Meckling, W. H. (1976). Theory of the firm: managerial behavioragency and ownership structure. Journal of Financial Economics, 3, 305-360. https://doi.org/10.1016/0304-405X(76)90026-X

Jiao, T., Koning, M., Mertens, G., \& Roosenboom, P. (2012). Mandatory IFRS adoption and its impact on analysts' forecasts. International Review of Financial Analysis, 21, 56-63. https://doi.org/10.1016/j.irfa.2011.05.006

Kasznik, R., \& McNichols, M. F. (2002). Does Meeting Expectations Matter? Evidence from Analyst Forecast Revisions and Share Prices. Journal of Accounting Research, 40, 727-759. https://doi.org/10.2139/sstn.189750

Kim, J.-B., \& Shi, H. (2012). Voluntary IFRS Adoption, Analyst Coverage, and Information Quality: International Evidence. Journal of International Accounting Research, 11(1), 45-76. https://doi.org/10.2308/jiar-10223

Kothari, S. P., Leone, A. J., \& Wasley, C. E. (2005). Performance matched discretionary accrual measures. Journal of Accounting and Economics, 39(1), 163-197. https://doi.org/10.1016/i.jacceco.2004.11.002

Martinez, A. L. (2010). Analysts as Gatekeepers in Brazil: Analysts' Coverage and Earnings Management. In SSRN. https://doi.org/10.2139/ssrn.1595086

Matsunaga, S. R., \& Park, C. W. (2001). The Effect of Missing a Quarterly Earnings Benchmark on the CEO's Annual Bonus. The Accounting Review, 76(3), 313-332. https://doi.org/10.2308/accr.2001.76.3.313

Montoya, J. C. C. (2018). The impact of IFRS on financial report quality in Latin America and the Caribbean. Accounting and Management, 63(2), 1-21.

Ortega, X. D. (2012). The Trade-Off Between Accounting Comparability and Representational Faithfulness with Mandatory International Financial Reporting Standards Adoption. The University of Utah.

Pelucio-Grecco, M. C., Geron, C. M. S., Grecco, G. B., \& Lima, J. P. C. (2014). The effect of IFRS on earnings management in Brazilian non-financial public companies. Emerging Markets Review, 21, 42-66. https://doi.org/10.1016/j.ememar.2014.07.001

Scott, W. R. (2014). Financial Accounting Theory (7th ed.). Canada: Pearson.

Tan, H., Wang, S., \& Welker, M. (2011). Analyst following and forecast accuracy after mandated IFRS adoptions. Journal of Accounting Research, 49(5), 1307-1357. https://doi.org/10.1111/i.1475-679X.2011.00422.x

Tze-yu, Y., Ming-lei, C., \& Hsiao-chian, Y. (2013). Does International Financial Reporting Standards (IFRS) Adoption Matter? The Effects on Financial Transparency and Earnings Management. Journal of Modern Accounting and Auditing, 9(6), 756-776. 
Wang, Y., Hou, Y., \& Chen, X. (2012). Accounting standard changes and foreign analyst behavior: Evidence from China. China Journal of Accounting Research, 5(1), 27-43. https://doi.org/10.1016/j.cjar.2012.02.001

Xu, B., Li, K., \& Liu, L. (2013). Research on Decision-Making Behavior of Analysts Coverage and Real and Accrual Earnings Management Based on SPSS Software Technology. Applied Mechanics and Materials, 411-414, 2571-2575. https://doi.org/10.4028/www.scientific.net/amm.411-414.2571

Yu, F. (Frank). (2008). Analyst coverage and earnings management. Journal of Financial Economics, 88(2), 245-271. https://doi.org/10.1016/j.jfineco.2007.05.008

Zeghal, D., Chtourou, S. M., \& Fourati, Y. M. (2012). The Effect of Mandatory Adoption of IFRS on Earnings Quality: Evidence from the European Union. Journal of International Accounting Research, 11(2), 1-25. https://doi.org/10.2308/jiar-10221

Zeghal, D., Chtourou, S., \& Sellami, Y. M. (2011). An analysis of the effect of mandatory adoption of IAS/IFRS on earnings management. Journal of International Accounting, Auditing and Taxation, 20(2), 61-72.

https://doi.org/10.1016/j.intaccaudtax.2011.06.001 